JKM (Jurnal Kebidanan Malahayati),Vol 7,No.3.Juli 2021,

ISSN (Print) 2476-8944 ISSN (Online) 2579-762X, Hal 489-494

\title{
KORELASI KADAR HEMOGLOBIN DENGAN LAJU FILTRASI GLOMERULUS PADA PASIEN GAGAL GINJAL KRONIK STADIUM 3 DAN 4
}

\author{
Siska Monika Faridz', Syuhada², Akhmad Kheru \\ 1,2,3 Prodi Kedokteran Universitas Malahayati \\ Email : siskamf17@gmail.com
}

\section{ABSTRACT HEMOGLOBIN LEVELS CORRELATION WITH GLOMERULUS FILTRATION IN CHRONIC STADIUM 3 AND 4 RENAL FAILURE PATIENTS}

Background Chronic kidney disease was one of the 18 causes of death in 2010. Anemia is a complication of CKD that often occurs even earlier than other complications. Renal dysfunction results in reduced creatinine filtration ability and an increase in serum creatinine.

Purpose of this study was to determine the correlation between hemoglobin levels and glomerular filtration rate in patients with stage 3 and 4 chronic kidney failure at Abdul Moeloek Hospital in Bandar Lampung in 2020.

Methods This type of research is quantitative with retrospective analytical methods. The research was conducted at the Medical Records section of the Abdul Moeloek Hospital Bandar Lampung from December 2020 to completion. The number of samples as many as 36 people using the person correlation statistical test.

Result Based on the results of the Pearson correlation analysis between hemoglobin levels and glomerular filtration rate in patients with stage 3 and 4 chronic kidney failure at Abdul Moeloek Hospital, Bandar Lampung, 2020 shows a relationship with $r$ (correlation coefficient) of, 688. This data shows that there is a positive relationship between hemoglobin levels and glomerular filtration rate in patients with stage 3 and 4 chronic renal failure at Abdul Moeloek Hospital, Bandar Lampung in 2020, the relationship is categorized as a strong relationship (0.61-0.80). . The P-value $=0,000$ indicates a significant relationship between hemoglobin levels and glomerular filtration rate in patients with stage 3 and 4 chronic renal failure at Abdul Moeloek Hospital Bandar Lampung in 2020.

Conclusion There is a correlation between hemoglobin levels and glomerular filtration rate in patients with stage chronic renal failure. 3 and 4 at Abdul Moeloek Hospital in Bandar Lampung in 2020

Suggestions for the Community The community is expected to seek information regarding the prevention of kidney failure and then start living a healthy lifestyle to avoid kidney failure. For patients with kidney failure, they should regularly check themselves to the nearest health facility and check creatinine and hemoglobin levels.

Keywords: Chronic renal failure, Creatinine, Hemoglobin, Glumerular Filtration Rate

\section{ABSTRAK}

Latar Belakang Penyakit ginjal kronik salah satu penyebab kematian ke-18 pada tahun 2010. Anemia merupakan salah satu komplikasi PGK yang sering terjadi bahkan terjadi lebih awal dari komplikasi lainnya. Disfungsi ginjal mengakibatkan kemampuan filtrasi kreatinin akan berkurang dan akan terjadi peningkatan pada kreatinin serum.

Tujuan penelitian ini untuk mengetahui korelasi antara kadar hemoglobin dengan laju filtrasi glomerulus pada pasien gagal ginjal kronik stadium 3 dan 4 di Rumah Sakit Abdul Moeloek Bandar Lampung Tahun 2020.

Metode Jenis penelitian ini adalah kuantitatif dengan metode analitik retrospektif. Penelitian dilakukan di bagian Rekam Medik Rumah Sakit Abdul Moeloek Bandar Lampung pada bulan Desember 2020 hingga selesai. jumlah sampel sebanyak 36 orang menggunakan uji statistic korelasi person. Berdasarkan hasil analisi korelasi Pearson antara kadar hemoglobin dengan laju filtrasi glomerulus pada pasien gagal ginjal kronik stadium 3 dan 4 di Rumah Sakit Abdul Moeloek Bandar Lampung Tahun 2020 menunjukan adanya hubungan dengan r (koefisien korelasi) sebesar ,688.

Hasil Data ini menunjukan bahwa terdapat hubungan positif antara kadar hemoglobin dengan laju filtrasi glomerulus pada pasien gagal ginjal kronik stadium 3 dan 4 di Rumah Sakit Abdul Moeloek Bandar Lampung Tahun 2020 hubunganya dikategorikan sebagai hubungan yang kuat (strong) $(0,61-0,80)$. Nilai P-value $=0,000$ menunjukan hubungan signifikan antara kadar hemoglobin dengan laju filtrasi glomerulus pada pasien gagal ginjal kronik stadium 3 dan 4 di Rumah Sakit Abdul Moeloek Bandar Lampung Tahun 2020. 
Kesimpulan Terdapat korelasi antara kadar hemoglobin dengan laju filtrasi glomerulus pada pasien gagal ginjal kronik stadium 3 dan 4 di Rumah Sakit Abdul Moeloek Bandar Lampung Tahun 2020.

Saran Bagi Masyarakat Masyarakat diharapkan mencari informasi terkait penegahan penyakit gagal ginjal kemudian mulai menjalani gaya hidup sehat agar terhindar dari penyakit gagal ginjal. Bagi penderita gagal ginjal agar rutin memeriksanakn diri ke fasilitas kesehatan terdekat dan memeriksakan kadar kreatinin serta hemoglobin.

Kata Kunci : Gagal ginjal kronik, Kreatinin, Hemoglobin, Laju Filtrasi Glumerulus

\section{PENDAHULUAN}

Penyakit ginjal kronik adalah suatu proses patofisiologis dengan etiologi yang beragam, PGK menyebabkan penurunan fungsi ginjal yang progresif, serta umumnya dapat terjadi dengan gagal ginjal. Penurunan fungsi ginjal ditandai dengan laju filtrasi glomerulus (LFG) kurang dari $60 \mathrm{ml} / \mathrm{menit} / 1,73 \mathrm{~m} 2$ (Suwitra Ketut, 2017).

Saat ini penyakit ginjal kronik (PGK) di dunia sedang mengalami peningkatan serta menjadi urusan kesehatan yang serius, hasil penelitian Global Burden of Disease pada tahun 2010, PGK salah satu penyebab kematian ke-27 di dunia pada tahun 1990 dan terjadi peningkatan menjadi urutan ke-18 pada tahun 2010 (Riskesdas, 2013).

Ginjal merupakan sumber utama eritropoietin yaitu faktor pertumbuhan hematopoietik yang memacu pembentukan eritrosit. Eritropoietin dapat meningkatkan produksi retikulosit dan pelepasan dini retikulosit dari sumsum tulang, ketika kadar eritropoietin menurun maka kadar hemoglobin juga menurun (Guyton, 2016).

Penurunan fungsi ginjal terjadi akibat berkurangnya unit struktural ginjal yang masih berfungsi baik. Penurunan fungsi ginjal ini dapat diketahui dengan cara menghitung nilai laju filtrasi glomerulus melalui rumus Cockcroft-Gault atau MDRD (Modification of Diet in Renal Disease). Penurunan laju filtrasi glomerulus ini berhubungan dengan manifestasi klinik yang akan ditemukan pada pasien PGK. Salah satu manifestasi klinik yang sering menyerang PGK adalah penurunan kadar hemoglobin atau hematokrit dalam darah atau biasa disebut anemia (Hidayat, 2016).

Berdasarkan penelitian Patrick (2020), menunjukan hasil penelitian tersebut ada hubungan antara kadar hemoglobin dengan laju filtrasi glomerulus pada pasien gagal ginjal kronik stadium 3 dan 4. Namun, berdasarkan hasil penelitian Bhatta (2011), menunjukan tidak ada hubungan signifikan antara kadar hemoglobin dengan kadar kreatinin serum pada pasien gagal ginjal kronik.

Tujuan penelitian ini adalah untuk mengetahui korelasi antara kadar hemoglobin dengan laju filtrasi glomerulus pada pasien gagal ginjal kronik stadium 3 dan 4 di Rumah Sakit Abdul Moeloek Bandar Lampung Tahun 2020.

\section{METODOLOGI PENELITIAN}

Jenis penelitian ini adalah kuantitatif dengan metode analitik retrospektif, dilakukan di bagian Rekam Medik Rumah Sakit Abdul Moeloek Bandar Lampung pada bulan Desember 2020 hingga selesai serta telah melewati izin etik penelitian. Populasi pasien gagal ginjal kronik pada bulan januari - oktober tahun 2020 di Rumah Sakit Abdul Moeloek Bandar Lampung berjumlah 93 orang kemudian di tentukan jumlah sampel sebanyak 36 orang menggunakan teknik sampling nonprobability sampling jenis consecutive sampling. Penelitan ini memiliki kriteria inklusi yaitu Pasien yang terdiagnosis gagal ginjal kronik stadium 3 dan 4 yang memiliki data rekam medik dengan hasil pemeriksaan penunjang berupa kadar hemoglobin dan laju filtrasi glomerulus yang lengkap di Rumah Sakit Abdul Moeloek tahun 2020. Memiliki kriteria eklusi Pasien yang terdiagnosis gagal ginjal kronik yang telah melakukan tindakan intervensi berupa erythropoietin stimulating agent (ESA), suplementasi besi, dan transfusi darah, pasien yang terdiagnosis gagal ginjal kronik dengan thalasemia, perdarahan, hemoglobinopati, keganasan dan HIV. Pasien yang terdiagnosis gagal ginjal kronik yang tidak memiliki data rekam medik dengan hasil pemeriksaan penunjang yang lengkap. Instrumen penelitian menggunakan aplikasi IBM SPSS 21.0 dengan uji statistic uji korelasi person.

\section{HASIL DAN PEMBAHASAN}

Tabel 1.

Karakteristik Responden berdasarkan Usia

\begin{tabular}{lcc}
\hline \multicolumn{1}{c}{ Usia } & Frekuensi & $\begin{array}{c}\text { Persentase } \\
(\%)\end{array}$ \\
\hline Remaja akhir (17-25 thn) & 1 & $2.8 \%$ \\
Dewasa awal (26-35 thn) & 1 & $2.8 \%$ \\
Dewasa Akhir (36-45 thn) & 5 & $13.9 \%$ \\
Lansia Awal (46-55 thn) & 13 & $36.1 \%$ \\
Lansia Akhir (56-65 thn) & 14 & $38.9 \%$ \\
Manula > 65 thn & 2 & $5.6 \%$ \\
\hline \multicolumn{1}{c}{ Total } & 36 & $100 \%$ \\
\hline
\end{tabular}


JKM (Jurnal Kebidanan Malahayati),Vol 7,No.3.Juli 2021,

ISSN (Print) 2476-8944 ISSN (Online) 2579-762X, Hal 489-494

Dari tabel di atas didapatkan bahwa 14 (38.9\%) responden termasuk dalam kategori usia lansia akhir berdsarkan kategori usia depkes RI
2009, dan hanya sebanyak $1(2,8 \%)$ responden termasuk dalam kategori usia Remaja akhir dan Dewasa awal.

Tabel 2.

Rerata Usia, kreatinin Serum, Hemoglobin, Berat badan, dan Laju Filtrasi Glumerulus

\begin{tabular}{lccccc}
\hline \multicolumn{1}{c}{ Frekuensi } & Mean & Median & Std. Dev & Min & Maks \\
\hline Usia & 52.03 & 54.50 & 9.961 & 23 & 68 \\
Kreatinin Serum & 4.68 & 4.86 & 1.59 & 0.93 & 6.98 \\
Hemoglobin & 9.62 & 9.30 & 2.45 & 5.70 & 16.10 \\
Berat Badan & 68.16 & 67.50 & 9.24 & 45 & 89 \\
Laju Filtrasi Glumerulus & 20.36 & 16 & 9.44 & 15 & 54 \\
\hline
\end{tabular}

Dari tabel di atas di dapatkan rata-rata usia responden adalah 52 tahun dengan usia maksimal 68 tahun dan usia minimal 23 tahun. Rata-rata Kadar kreatinin serum responden adalah 4.68 $\mathrm{mg} / \mathrm{dL}$ dengan Kadar kreatinin serum maksimal $6,98 \mathrm{mg} / \mathrm{dL}$ dan Kadar kreatinin serum minimal 0,93 $\mathrm{mg} / \mathrm{dL}$. Rata-rata Kadar Hemoglobin responden adalah 9,62 $\mathrm{mg} / \mathrm{dL}$ dengan Kadar Hemoglobin maksimal 16,10 mg/dL dan Kadar Hemoglobin minimal $5,70 \mathrm{mg} / \mathrm{dL}$. Rata-rata Berat badan responden adalah $68,16 \mathrm{~kg}$ dengan Berat badan maksimal $89 \mathrm{~kg}$ dan Kadar Berat badan minimal 45 kg. Rata-rata Laju Filtrasi Glumerulus responden adalah 20,36 dengan Laju Filtrasi Glumerulus maksimal 54 dan Laju Filtrasi Glumerulus minimal 15.

Tabel 3.

Distribusi Frekuensi Responden berdasarkan kadar $\mathrm{Hb}$

\begin{tabular}{ccccccc}
\hline Kadar Hemoglobin & \multicolumn{2}{c}{ Stage 3 } & \multicolumn{2}{c}{ Stage 4 } & \multicolumn{2}{c}{ Jumlah } \\
\hline Anemia $(<14 \mathrm{gr} / \mathrm{dL})$ & 1 & $2,8 \%$ & 31 & $86,1 \%$ & 32 & $88,9 \%$ \\
Normal $(14-18 \mathrm{gr} / \mathrm{dL})$ & 4 & $11,1 \%$ & 0 & $0 \%$ & 4 & $11,1 \%$ \\
\hline Total & 5 & $13,9 \%$ & 31 & $86,1 \%$ & 36 & $100 \%$ \\
\hline
\end{tabular}

Dari tabel di atas didapatkan bahwa 32 $(88.9 \%)$ responden menderita anemia terdiri dari 1 $(2,8 \%)$ resonden Laju Filtrasi Glumerulus Stage 3 dan $31(86,1 \%)$ responden dengan Laju Filtrasi Glumerulus Stage 4, dan hanya sebanyak $4(11,1$
\%) responden memiliki kadar $\mathrm{Hb}$ normal terdiri dari $4(13,9 \%)$ resonden Laju Filtrasi Glumerulus Stage 3 dan tidak ada responden dengan Laju Filtrasi Glumerulus pada Stage 4.

Tabel 4.

Distribusi Frekuensi Responden berdasarkan kadar Kreatinin

\begin{tabular}{lcccccc}
\hline \multicolumn{1}{c}{ Kadar Kreatinin } & \multicolumn{2}{c}{ Stage 3 } & \multicolumn{2}{c}{ Stage 4 } & \multicolumn{2}{c}{ Jumlah } \\
\hline Normal $(0,7-1,3 \mathrm{mg} / \mathrm{dL})$ & 2 & $5,6 \%$ & 0 & $0 \%$ & 2 & $5,6 \%$ \\
Tidak normal (Tinggi) $(>1,3 \mathrm{mg} / \mathrm{dL})$ & 3 & $8,3 \%$ & 31 & $86,1 \%$ & 34 & $94,4 \%$ \\
\hline \multicolumn{1}{c}{ Total } & 5 & $13,9 \%$ & 31 & $86,1 \%$ & 36 & $100 \%$ \\
\hline
\end{tabular}

Dari tabel di atas didapatkan bahwa 34 $(94,4 \%)$ responden memiliki kadar kreatinin serum yang tinggi yang terdiri dari $3(8,3 \%)$ resonden Laju Filtrasi Glumerulus Stage 3 dan 31 $(86,1 \%)$ responden dengan Laju Filtrasi Glumerulus Stage 4, dan hanya sebanyak $2 \quad(5,6 \%)$ responden yang memiliki kadar kreatinin serum normal yang terdiri dari $2(5,6 \%)$ resonden Laju Filtrasi Glumerulus Stage 3 dan tidak ada responden dengan Laju Filtrasi Glumerulus Stage 4.
Dari tabel di bawah didapatkan bahwa 31 $(86.1 \%)$ responden memiliki Laju Filtrasi Glumerulus pada Stage 4 (LFG 15-29m//menit), dan sebanyak $5(13,9 \%)$ responden yang memiliki Laju Filtrasi Glumerulus Stage 3 (LFG 30$59 \mathrm{ml} / \mathrm{menit})$. 
Tabel 5.

Distribusi Frekuensi Responden berdasarkan nilai LFG

\begin{tabular}{lcc}
\hline \multicolumn{1}{c}{$\begin{array}{c}\text { Laju Filtrasi } \\
\text { Glumerulus }\end{array}$} & Frekuensi & $\begin{array}{c}\text { Persentase } \\
(\%)\end{array}$ \\
\hline $\begin{array}{l}\text { Stage 3 } \\
\text { (LFG 30-59ml/menit) }\end{array}$ & 5 & $13,9 \%$ \\
$\begin{array}{l}\text { Stage 4 } \\
\text { (LFG 15-29ml/menit) }\end{array}$ & 31 & $86.1 \%$ \\
\hline \multicolumn{1}{c}{ Total } & 36 & $100 \%$ \\
\hline
\end{tabular}

Tabel 6.

Hasil Analisis Uji Pearson

\begin{tabular}{lccc}
\hline & N & $\begin{array}{c}\text { Sig. (2- } \\
\text { tailed) }\end{array}$ & $\begin{array}{c}\text { Pearson } \\
\text { Correlation }\end{array}$ \\
\hline LFG_KEL & 36 & 0,000 & 0,688 \\
\hline HB & & \\
\hline${ }^{* *}$. Correlation is significant at the 0.01 level (2-tailed).
\end{tabular}

Berdasarkan tabel 6 didapatkan hasil analisi korelasi Pearson antara kadar hemoglobin dengan laju filtrasi glomerulus pada pasien gagal ginjal kronik stadium 3 dan 4 di Rumah Sakit Abdul Moeloek Bandar Lampung Tahun 2020 menunjuan adanya hubungan dengan $r$ (koefisien korelasi) sebesar ,688. Data ini menunjukan bahwa terdapat hubungan positif antara kadar hemoglobin dengan laju filtrasi glomerulus pada pasien gagal ginjal kronik stadium 3 dan 4 di Rumah Sakit Abdul Moeloek Bandar Lampung Tahun 2020 hubunganya dikategorikan sebagai hubungan yang kuat (strong) $(0,61-0,80)$. Nilai P-value $=0,000$ menunjukan hubungan signifikan antara kadar hemoglobin dengan laju filtrasi glomerulus pada pasien gagal ginjal kronik stadium 3 dan 4 di Rumah Sakit Abdul Moeloek Bandar Lampung Tahun 2020.

\section{PEMBAHASAN}

Berdasarkan hasil analisi korelasi Pearson antara kadar hemoglobin dengan laju filtrasi glomerulus pada pasien gagal ginjal kronik stadium 3 dan 4 di Rumah Sakit Abdul Moeloek Bandar Lampung Tahun 2020 menunjuan adanya hubungan dengan $r$ (koefisien korelasi) sebesar ,688. Data ini menunjukan bahwa terdapat hubungan positif antara kadar hemoglobin dengan laju filtrasi glomerulus pada pasien gagal ginjal kronik stadium 3 dan 4 di Rumah Sakit Abdul Moeloek Bandar Lampung Tahun 2020 hubunganya dikategorikan sebagai hubungan yang kuat (strong) $(0,61-0,80)$. Nilai P-value $=0,000$ menunjukan hubungan signifikan antara kadar hemoglobin dengan laju filtrasi glomerulus pada pasien gagal ginjal kronik stadium 3 dan 4 di Rumah Sakit Abdul Moeloek Bandar Lampung Tahun 2020.

Penelitian ini sejalan dengan Rosnety (2007) menemukan bahwa anemia sudah mulai terjadi di penderita PGK dengan kadar kreatinin serum 2,0 $\mathrm{mg} / \mathrm{dl}$, tetapi kelainan yang jelas tampak bila LFG < 20-35 $\mathrm{ml} / \mathrm{menit}$. Derajat anemia yang terjadi bergantung pada berat ringan kerusakan ginjal. Anemia akan bertambah berat dengan semakin menurunnya fungsi ginjal.(Garini,2018) Penelitian ini menggunakan uji statistik nonparametrik (uji Kolmogorov-Smirnov) dan diperoleh nilai $p=0,013$ $(p<0,05)$.

Penelitian ini juga sejalan dengan penelitian Patrick (2020) terdapat hubungan linier positif yang berarti semakin rendah LFG maka kadar $\mathrm{Hb}$ akan semakin rendah. Pada penelitian ini variabel yang diteliti ialah kadar $\mathrm{Hb}$ dan LFG. Berdasarkan hasil analisis bivariat menggunakan uji korelasi Pearson antara kadar $\mathrm{Hb}$ dan LFG didapatkan adanya hubungan bermakna dengan nilai $p=0,027$ dan menunjukkan korelasi positif dengan nilai $r=0,312$.

Hasil penelitian lainnya yang mendukung hal ini ialah penelitian yang dilakukan oleh Suega (2012) pada 80 pasien PGK predialisis di RSUP Sanglah Denpasar, Bali tahun 2010 yang melaporkan bahwa terdapat $41 \%$ pasien PGK predialisis yang memiliki penurunan kadar $\mathrm{Hb}$. Penelitian tersebut dilakukan menggunakan uji korelasi Pearson terhadap hubungan antara kadar $\mathrm{Hb}$ dan LFG dan didapatkan hubungan positif yang bermakna dengan nilai $p=0,00$ dan $r=0,76$ yang berarti penurunan kadar $\mathrm{Hb}$ memiliki hubungan dengan menurunnya LFG. Hal ini juga sejalan dengan penelitian yang dilakukan oleh Apriani (2014) pada 60 pasien PGK dengan menggunakan data rekam medik di Instalasi Rekam Medik Rumah Sakit Umum Daerah dr. Sayyidiman Magetan tahun 2013, dimana terdapat korelasi positif antara penurunan kadar $\mathrm{Hb}$ dan LFG pada pasien dengan kadar LFG.

Anemia merupakan komplikasi GGK yang sering terjadi dan biasanya terjadi paling awal dibandingkan komplikasi yang lain.(Wong,2017). Anemia dapat menandakan keadaan kurangnya kadar hemoglobin, hematokrit, atau jumlah sel darah merah yang merupakan tanda dari suatu penyakit yang harus dicari penyebabnya, salah satunya penyakit gagal ginjal kronis . Anemia pada GGK dapat terjadi akibat defisiensi eritropoietin, pemendekan usia eritrosit, dan kehilangan darah. Menurut NHANES III, pada pasien pradialisis dengan laju filtrasi glomerulus (LFG) $<60$ $\mathrm{ml} /$ menit/1,73 $\mathrm{m} 2$ atau pada GGK dengan stadium $3-5$, kejadian anemia dengan kadar hemoglobin < 
$12 \mathrm{~g} / \mathrm{dl}$ adalah sebesar $50 \%$ (Maulidya, N., et al, 2016).

Anemia sudah mulai terjadi di penderita PGK dengan kadar kreatinin serum 2,0 mg/dL, tetapi kelainan yang jelas tampak bila LFG kurang dari 20-35 ml/menit.(Aprilia,2019). Kreatinin merupakan hasil penguraian kreatin, yaitu senyawa yang mengandung nitrogen, yang terutama terdapat di otot. Di setiap orang, jumlah kreatinin yang dihasilkan dari perputaran kreatin cenderung tetap (konstan). Jumlah yang dihasilkan dan dibuang (ekskresi) setara dengan massa otot dan biasanya lebih tinggi di laki-laki dibanding dengan perempuan. Buangan (Ekskresi) kreatinin merupakan indeks yang bermanfaat untuk kegiatan (aktivitas) ginjal dan keseragaman pengumpulan air kemih (urin). Setiap orang mengeluarkan sejumlah kreatinin setiap hari yang lebih bergantung pada massa otot total daripada kegiatan (aktivitas) otot atau tingkat metabolisme protein walaupun keduanya juga menimbulkan akibat (efek)(Yudianto,2020). Kreatinin serum meningkat apabila fungsi ginjal menurun. Apabila penurunan fungsi ginjal yang berlangsung secara lambat bersamaan dengan penurunan massa otot, kepekatan (konsentrasi) kreatinin dalam serum mungkin menjadi mantap (stabil), tetapi angka pembuangan (ekskresi) 24 jam akan lebih rendah daripada normal. Anemia akan lebih berat jika fungsi ginjal menjadi lebih buruk, tetapi apabila penyakit ginjal telah mencapai stadium akhir anemia nisbi (relative) akan menetap. Apabila pada stadium akhir PGK anemia memburuk, harus dipikirkan terjadinya penyulit (komplikasi), misalnya perdarahan gastrointestinal (Arif, M. 2018).

\section{SIMPULAN}

Terdapat korelasi antara kadar hemoglobin dengan laju filtrasi glomerulus pada pasien gagal ginjal kronik stadium 3 dan 4 di Rumah Sakit Abdul Moeloek Bandar Lampung Tahun 2020.

\section{SARAN}

Saran yang dapat diberikan berdasarkan hasil penelitian dan pembahasan yang telah dilakukan antara lain sebagai berikut: Bagi Masyarakat Masyarakat diharapkan mencari informasi terkait penegahan penyakit gagal ginjal kemudian mulai menjalani gaya hidup sehat agar terhindar dari penyakit gagal ginjal. Bagi penderita gagal ginjal agar rutin memeriksanakn diri ke fasilitas kesehatan terdekat dan memeriksakan kadar kreatinin serta hemoglobin. Bagi Instansi Kesehatan Bagi Dinas Kesehatan, Puskesmas dan instansi terkait untuk melakukan edukasi bagaimana pencegahan gagal ginjal dan memberikan pemeriksaan rutin kreatinin serum dan hemoglobin kepada penderita gagal ginjal. Bagi Peneliti lain Peneliti menyarankan untuk dilakukan penelitian lebih lanjut untuk mengetahui kadar hemoglobin dengan laju filtrasi glomerulus pada pasien

\section{DAFTAR PUSTAKA}

Aprillia, D. (2019). Penyakit Ginjal Kronis pada Kehamilan. Jurnal Kesehatan Andalas, 8(3), 708-716.

Apriani Y. (2014) Korelasi antara penurunan laju filtrasi glomerulus dengan beratnya anemia pada penyakit ginjal kronik di RSUD DR. Sayyidiman Magetan [Disertasi]. Surakarta: Universitas Muhammadiyah Surakarta

Arif, M. (2018). Hubungan Antara Kadar Hemoglobin Dengan Kadar Kreatinin Serum Penderita Penyakit Ginjal Menahun (Kronis). Indonesian Journal of Clinical Pathology And Medical Laboratory, 13(3), 97-99.

Bhatta, S., Aryal, G., \& Kafle, R. K. (2011). Anemia in chronic kidney disease patients in predialysis and postdialysis stages. Journal of Pathology of Nepal, 1(1), 26-29.

Garini, A. (2018). Kadar Hemoglobin Pada Pasien Gagal Ginjal Kronik Yang Menjalani Hemodialisis. JPP (Jurnal Kesehatan Poltekkes Palembang), 13(2), 111-116.

Guyton, Ermita I. Ibrahim llyas editorial. (2016). Guyton dan Hall : Buku Ajar Fisiologi Kedokteran Edisi Revisi Berwarna Ke-12. Singapura : Elsevier Singapore

Hidayat, R., Azmi, S., \& Pertiwi, D. (2016). Hubungan Kejadian Anemia dengan Penyakit Ginjal Kronik pada Pasien yang Dirawat di Bagian IImu Penyakit Dalam RSUP dr M Djamil Padang Tahun 2010. Jurnal Kesehatan Andalas, 5(3).

Kemenkes Ri. (2013). Riset Kesehatan Dasar; RISKESDAS. Jakarta: Balitbang Kemenkes $\mathrm{Ri}$

Maulidya, N., Arifin, M., \& Yuliana, I. (2016). Gambaran Jenis Anemia Menggunakan Mean Corpuscular Hemoglobin (Mch) Pada Gagal Ginjal Kronik. Berkala Kedokteran, 12(2), 187-195.

Patrick, F. M., Umboh, O. R., \& Rotty, L. W. (2020). Hubungan Kadar Hemoglobin dengan Laju Filtrasi Glomerulus pada Pasien Penyakit Ginjal Kronik Stadium 3 dan 4 Di RSUP Prof. Dr. RD Kandou Manado Periode Januari 2017-Desember 2018. e-CliniC, 8(1). 
Rosnety, Arif, M. (2007). Hubungan Antara Kadar Hemoglobin Dengan Kadar Kreatinin Serum Penderita Penyakit Ginjal Menahun (Kronis). Indonesian Journal Of Clinical Pathology And Medical Laboratory, 13(3), 97-99.

Suega K. (2012) Hubungan antara beberapa parameter anemi dan laju filtrasi glomerulus pada penyakit ginjal kronik pradialisis. Jurnal Penyakit Dalam. Sep:140.

Suwitra Ketut.(2017). Penyakit Ginjal Kronik. Siti Setiati, Idrus Alwi, Aru W. Sudoyo dkk.
Dalam: Buku Ajar IImu Penyakit Dalam. Edisi 6. Jakarta: Interna Publishing.

Yudianto, A. (2020). IImu kedokteran forensik. SCOPINDO MEDIA PUSTAKA.

Wong, O. A., \& Sarjana, D. S. S. M. G. (2017). Analisis perubahan hemoglobin pada pasien gangguan ginjal kronik (GGK) yang menjalani Hemodialisa selama 3 Bulan di Rumah Sakit Perguruan Tinggi Negeri (RSPTN) Universitas Hasannudin (UNHAS) Makassar [skripsi]. Makasar: Skripsi FK Universitas Hasanuddin Makasar, 1-83. 